\title{
Why history matters: The place of historical consciousness in a multidimensional approach towards biblical interpretation
}

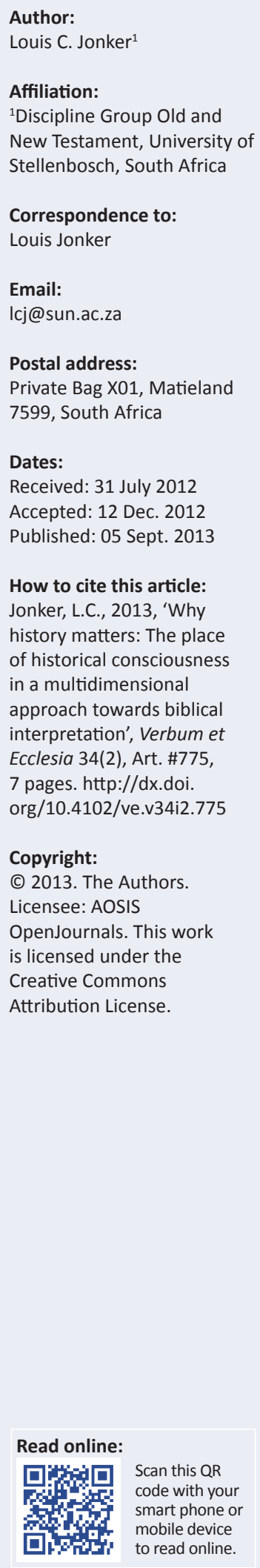

Since the linguistic turn of New Criticism and the advent of reader-response approaches in the previous century, the category of history has come under pressure in biblical interpretation. New developments in general historiography have also emphasised that the past is forever past, and that only constructions of the past remain. These developments bring many to the conclusion that the past offers no assistance in the interpretation process. In my paper I would like to re-emphasise that 'historical consciousness' does not mean an anachronistic clinging to something which no longer exists, but rather refers to the ability to sense the multidimensionality of interpretation, particularly in the case of ancient biblical texts.

\section{Introduction}

A few months ago I was involved in a discussion with a scholar about some parts of a new book that the person is conceptualising at the moment. I had criticism against a distinction made in the discussed part of the manuscript between intrinsic and extrinsic factors determining the interpretation of literature in general, and biblical literature in particular. When discussing the intrinsic factors, I tried to indicate that rhetorical and/or narrative features of a text cannot be understood in isolation, devoid from any historical context in which the communication functioned. I emphasised that communication (also textual communication) never happens in a vacuum, and that the historical dimension of interpretation should always be taken into account; thus my criticism of the distinction between intrinsic and extrinsic factors determining interpretation.

The discussion that followed convinced me that I failed to communicate clearly what I mean with the historical dimension in interpretation, or with the reference to historical consciousness which I see as of cardinal importance in the interpretation process. Some participants in the discussion thought that I was arguing for some sort of a reconstruction of the original context, or that I was stepping into the trap of trying to identify the intention of the author. Some thought that I was confusing the real author and the implied author of texts, and indicated that the real author can never be recovered.

This brought me back to a renewed reflection on why history matters in interpretation, Old Testament interpretation in particular, and how this can be communicated within the framework of a multidimensional approach to exegesis. This contribution is an attempt to clarify my understanding of historical consciousness in Old Testament interpretation. ${ }^{1}$ I will first distinguish four different, but overlapping, debates on how the historical functions in biblical interpretation (particularly in the South African context). Thereafter, I will briefly dwell on a South African contribution to these debates. My aim in a next section will be to relate the debate on historical consciousness to the debate on contextual interpretation. My hypothesis for this study is that emphasis on the analogy between contexts of textual production and textual reception (in ancient and contemporary contexts) can bring about a better articulation of why historical consciousness is indispensable in biblical interpretation.

\section{(At least) Four debates about the historical in Old Testament interpretation}

At least four debates had dominated, and are still dominating, discussions on biblical interpretation, internationally but also locally, in recent years. Although I am distinguishing between these different debates, they can never be separated or treated in isolation, and cannot be treated in any chronological order. With my distinction I would like to highlight, however,

1.It is an honour to dedicate this article to Jurie le Roux, who has been a champion of historical understanding of the Old Testament in South Africa throughout his career. See references to some of his publications in the remainder of this contribution. 
the different angles taken, or aspects emphasised, in these related debates.

The first is the historicity debate. This debate has been the feature of many biblical studies conferences over the past decades and has been documented in various international publications. ${ }^{2}$ There is thus no need to be too elaborate in my discussion. In Old Testament studies this debate has centred on the question of the value the Hebrew Bible has for the reconstruction of the (early) history of Israel. ${ }^{3}$ It has become customary to refer to the two extreme positions in this debate as maximalism and minimalism, ${ }^{4}$ with the former holding a position that the biblical writings can contribute maximally to a description of the events in the Ancient Israel which produced the Hebrew Bible, and the latter denying the historical validity of the biblical documents, which are considered to be subjective and biased and therefore not a reflection of true events of the past. Maximalists would argue that the biblical texts are primary witnesses in the reconstruction of Israel's past, whilst minimalists would depict them (at most) as secondary, or even tertiary, witnesses. According to the minimalists, one should rather rely on archaeological and extra-biblical information for reconstructing Israel's past. Although the international debate has developed in recent years to a point where more nuanced positions are taken, ${ }^{5}$ it still occurs (also in the South African context) that these extreme positions are voiced in literature.

One interesting voice in this debate from South Africa is Jurie le Roux. In a paper delivered at the International Organisation for the Study of the Old Testament (IOSOT) conference in Oslo, Norway, Le Roux (1998) stated the following:

The views of the so-called minimalists are stimulating, thoughtprovoking and of course a challenge to play with different readings of Israel's past. This article accepts the challenge by stating that we do not even have a minimum. We have nothing. It will be argued that the 'minimum' is actually a 'maximum': there are still too many certainties (the 'pastness' of the past has not yet been experienced as an irretrievable loss). Put differently: the 'minimum' of the so-called 'minimalists' must be deconstructed even further. (p. 477)

With his contribution Le Roux then shows that the same positivistic epistemology which is present in the maximalist

2.For good summaries of this debate, see inter alia Collins (2005:27-52), Grabbe (2004:2-21) and McKenzie (2005:23-66). For a recent collection of essays dealing with some aspects of the debate, see Davies (2010).

3.See, for example, Thompson (1999) where the author indicates how the biblical portrayal of history is a creative invention by its writers.

4.One of the main participants in the debate, who is often indicated to be a 'minimalist', protests against the use of this concept. Philip Davies (n.d.) states the following about the use of the term in an online contribution: 'Like its equivalents "revisionist," "nihilist," and "skeptic," it was coined by its opponents and is not supposed to be flattering. Why do its alleged proponents not have a name for themselves? I will explain presently. For the moment, let's discover what is so revealing about the term "minimalism." A clue lies in Baruch Halpern's essay on "minimalism" called "Erasing History" (Halpern 1995). Minimal history, one would think. But actually not: the charge is really having a minimum of biblical narrative in history. Halpern deliberately equates the two. Bible = history is an agenda of many anti-"minimalists," and it remains by and large the popular view of the Bible many anti- "minimalists," and it remains by and large the popular view of the Bible that losing the biblical narrative means losing history. "Minimalists" would say, of that losing the biblical narrative means losing hist

5.See, for example, the volume edited by Hardmeier (2001) in which biblical exegetes, archaeologists, epigraphers and iconographers contributed to a complementary understanding of these specialisation fields. position also lurks behind the minimalist position. Both positions assume that Israel's past can somehow be retrieved; the maximalists believe this can be done through the biblical writings, whilst the minimalists argue that the biblical writings are of minimal assistance, but that archaeology and extra-biblical literature can assist well in this regard. Le Roux therefore challenges the minimalists to accept the full consequence of the debate, namely the irretrievable 'pastness' of Israel's past. Historiography is never reconstruction, but always construction. How Le Roux argues that this can be done, will be elaborated upon below.

The second debate is a debate on textual growth and/or composition. It is namely all the various exegetical methods of the historical-critical approach which have put this issue on the table, particularly since Wellhausen's work in the middle of the 19th century. ${ }^{6}$ Although the issue of Israel's past (particularly its religious history) has been and remains an important interest in historical-critical studies, ${ }^{7}$ history features here more in the form of the history of texts, that is, as Literaturgeschichte (See, e.g., Schmid 2008). Retrieving the processes of textual growth and composition forms the primary interest of these studies. The assumption lurking behind this interest is namely that the meaning of the biblical texts is a function of the history of these texts, that is, of their growth and composition. Many (particularly German) studies have therefore been dedicated to trace the composition history of biblical texts to their minutest details.

Opposition to this mode of textual study, which still dominates European (particularly German) scholarship has been lodged in the aftermath of the emergence of New Criticism in the early half of the 20th century. The premise that the origin and history of texts contribute centrally to the meaning of texts, have therefore come under severe pressure in particularly the Anglo-Saxon world. Additionally, since the 1960s, with the advent of a whole array of reader-response approaches, the premise that the history of the biblical texts is determinative of their interpretation has been increasingly questioned, also in nontraditional scholarly contexts, such as in Africa. Scholars from these contexts have started to emphasise the role of the reader, and their social location, in the interpretation process, which led to the demise of the original contexts of textual production as determinative factor in interpretation. (These shifts will be discussed more fully below.)

Some redaction-historical studies, as well as studies focusing on inner-biblical exegesis, have taken another angle in this debate, however. In these approaches the processes of textual growth and composition are no longer studied from the production side, but rather from the reception side. Consecutive phases of textual growth are studied in order to determine how younger textual developments interpreted

6 .For an elaborate description of the history of historical-critical exegesis from Astruc to Zimmerli, see Smend (2007).

7.See, for example, the influential volumes on the history of Israel's religion by Albertz (1992), as well as the recent description of family religion in Ancient Israel in Albertz and Schmitt (2012). 
older traditions and, through a process of inner-textual exegesis, re-appropriated the older traditions in the changed contexts of a later present. ${ }^{8}$

A third debate which was and still is very influential in biblical interpretation is the intentional fallacy debate. Since the emergence of New Criticism in the first half of the 20th century general literary criticism started challenging historical modes of interpretation in which the intention of the author is assumed to be the determinative factor in interpretation. ${ }^{9}$ This debate, which became known as the intentional fallacy debate after the publication of W.K. Wimsatt and M.C. Beardsley's article in 1946, emphasised that 'the design or intention of the author is neither available nor desirable as a standard for judging the success of a work of literary art' (Wimsatt \& Beardsley 1954:3). This focus on the texts themselves as literary works of art also had an immense influence on biblical interpretation. Various modes of biblical interpretation arose in the aftermath of this debate in which the focus was exclusively on the texts and their structures. This so-called linguistic turn resulted in the historical being banned from the interpretation process. The meaning of biblical texts was no longer seen as a function of the history of development of these texts, but rather as a function of textual and structural features.

In an essay which was published in honour of Ferdinand Deist, Bosman (1992) participated in this debate by tracing the philosophical and hermeneutical understanding of authorial intention since the Enlightenment, and by showing how this impacted on the study of the Old Testament. He also traced further developments in the reflection on authorial intention to show that:

[t]he 'cluster of errors' centring on the concept of authorial intention has diminished during the past few decades and that many of the logical and empirical objections cannot be maintained any more. (Bosman 1992:29)

In his conclusion Bosman (1992) makes the following remarks:

[B]oth the author and the reader take part in the production of textual meaning and no single one is able to control meaning. Therefore authorial intention can never be considered to be the exclusive fountainhead of the meaning of a text - as some of the modern adherents to historical-criticism still presuppose. On the other hand, there seem to be many biblical scholars that still invoke 'intentional fallacy', without acknowledging that even the creators of the term 'intentional fallacy', Wimsatt and Beardsley, have conceded that there is such an entity .... This discussion of authorial intention need not be burdened with any Romantic speculation about the author's mind or the determining of the perennial meaning of the text. The acknowledgement of the existence of authorial intention does not of necessity lead to a 'fallacy', if the interpreter identifies the intention of the author primarily from the text itself. Therefore, above all, the integrity of the text must be maintained and this entails a sensitivity for the constraints imposed by the text on its reader. (p. 30)

8.See my discussion of the value of an inner-biblical exegesis approach in Jonker (2011). See also Schmid (2011).

9.For a short summary of this development, see Jonker and Lawrie (2005:67-78).
I will come back (in my discussion of the fourth debate below) to the implications which Bosman sees for biblical scholarship, particularly for those interpretations which shift the focus to the reader.

I would like to conclude the discussion of the intentional fallacy debate with an indication of its influence on South African biblical scholarship. Le Roux (1993a:27-28), in his description of 30 years of South African Old Testament scholarship in 1993, describes how influential a paper delivered in March 1971 by the New Testament scholar, Willem Vorster, was. Le Roux (1993a) indicates:

Vorster's paper reflected a specific approach (concentration on the final text and the rejection of information about the text's historical growth), as well as the terminology (diachrony, synchrony, structural analysis) that would be decisive for the future developments of biblical science in South Africa. (p. 28)

In my opinion, this development was also a result of the socalled linguistic turn brought about by the intentional fallacy debate. The texts themselves and their structures became the primary (if not only) locus of meaning for biblical scholars following this direction. The role of the historical therefore became minimised in biblical interpretation. This approach had tremendous influence in New Testament circles, ${ }^{10}$ but also in some parts of South African Old Testament scholarship. ${ }^{11}$

This brings me then to the fourth and last debate that I would like to highlight, namely the contextual debate. Since the 1960s the well-known shift in exegetical focus towards the text receiver's side and the role of the reader took place. ${ }^{12}$ Under the influence of various socio-political developments in the sixties and seventies this shift started dominating literary science in general, but also biblical scholarship. For those taking sides with the reader in the interpretation process, meaning is a function of the context of reception. Not the original circumstances or authorial intention, and also not the structures of the texts, but those interpreting the texts determine their meaning. There is no need to elaborate on this well-known shift in international biblical interpretation. I would rather highlight some local developments.

Two socio-political developments in the last part of the 20th century impacted strongly on biblical scholarship in South Africa, namely the anti-apartheid struggle, as well as the postcolonial awareness which arose since 1990 when Nelson Mandela was released and a new political dispensation was started. In Old Testament scholarship it was particularly Gerald West who started emphasising the context of the interpreter by his deliberate siding with the oppressed and the poor and his emphasis on a hermeneutics of liberation (See West 1995). Since the advent of democracy in South Africa various other voices started articulating interpretations which take African contexts of interpretation 10.See, as one example, how structural analysis was practised by Combrink (1979).

11.See particularly the extensive corpus of work done on the Psalms by Prinsloo (e.g. 1988 ) and his students. See also a description of the influence of text-immanent studies on Pentateuchal studies in South Africa in Le Roux (2007b).

12.For a brief summary of this shift, see Jonker and Lawrie (2005:109-112). 
seriously. ${ }^{13}$ Although the historical functions in various ways in the variety of (South) African interpretations, the primary focus is on the contextual nature of interpretation (See West 2005). Contextual biblical interpretation is therefore often contrasted with detached, historical interpretations which show no sensitivity for the context of the reader. In contextual biblical interpretation meaning is closely (if not exclusively) associated with the context of the interpreter.

At this point it could be interesting to return to Bosman's (1992) concluding remark in his article on intentional fallacy. He sounds the following warning:

The current emphasis on contextual understanding is both healthy and exciting. But there are disturbing signs that point to a certain 'orthopraxis', which is considered to be the only acceptable position from which to understand the biblical text. Without denying the important influence of the reader's context on the process of understanding, exegetes will have to be on the alert to the real danger that the historicity of the reader is overemphasized at the cost of the historicity of the author. A qualified utilising of authorial intent is not more of a hypothetical exercise than the reconstruction of the context of the reader and might even help to liberate interpreters from their view of 'orthopraxis', as it once set them free from crippling orthodoxy. (pp. 30-31)

Although I am in agreement with the view expressed here, I do not want to focus on the 'orthopractic' side of contextual interpretation for the moment. I would rather call attention to Bosman's relating of 'the historicity of the reader' to 'the historicity of the author'. In this formulation he is presupposing some sort of analogy between the historicity or context of the author and that of the reader, an understanding which I would like to explore further in a section below.

Before continuing to the next section let me re-articulate - in the light of these debates - the questions this paper tries to answer: Should we still emphasise the historical dimension in biblical interpretation? If so, what should a historical consciousness entail? How should we articulate it in order not to be misunderstood?

As I have indicated above, there is particularly one Old Testament scholar in South Africa today who is strongly in favour of a historical understanding of the Bible, namely Jurie le Roux. Before presenting my own understanding of the role of historical consciousness in Old Testament interpretation, I would like to focus more closely on how Le Roux involves the historical in his interpretation.

\section{Jurie Le Roux on historical understanding}

In many publications, Le Roux has articulated his views on historical understanding of the Old Testament in particular. In some he provided an overview of the way in which the

13.Particularly Madipoane Masenya (1996), Elelwani Farisani (2002) and Makhosazan Nzimande (2005) (to mention but a few) have made valuable contributions in South African Old Testament scholarship through their dissertations. See also West (2008) for a summary of postcolonial interpretation in (South) Africa. On wider African scale, numerous voices contribute to emphasising African contexts of interpretation. See, for example, the collection of essays edited by Ukpong et al. (2002) historical had featured in general philosophical reflection and in Old Testament scholarship since Gabler's work in the 18th century, and how this historical heritage should be appropriated in modern-day (South African) biblical scholarship (e.g. Le Roux 1993b; 1997). In others, he engaged in discussion with the so-called minimalists (1998), or indicated the implications of his understanding for New Testament scholarship, and for historical Jesus studies in particular (2007a). Recently he also evaluated some Pentateuch scholarship (particularly the input of Eckart Otto at ProPent) in light of his understanding of the historical in Old Testament science (2010). My aim is not to summarise all these and other publications of Le Roux, but rather to emphasise aspects which serve my present quest well, namely, why does history matter in our interpretations of the Old Testament?

Le Roux is very adamant that the past is forever past. Our interpretations of the Old Testament may therefore not rely on all kinds of positivistic history-writing which aim at establishing the factual events of the past. He puts it as follows:

Israel's past will ... forever evade us, the singularity of the event will never be known, the Old Testament scholar will always be in mourning over its loss and Israel's history will always be studied with tears (because its distinctiveness will never be grasped). To write a history of Israel is to know very well 'the quid' of the event is for ever lost. There is therefore no minimum left and minimalists do not actually exist. There are only trackers (historians) following the traces which were left by the past events. Out of these traces he [sic] can make his [sic] own story about the past. (Le Roux 1998:483)

If this is true, what should then be the focus of the Old Testament scholar? With reference to Collingwood, Le Roux makes the distinction between the 'outside' and the 'inside' of an event, with the latter presiding over the former. 'Outside' knowledge of the history of Israel is indispensable (e.g. information on the existence or non-existence of the Davidic-Solomonic kingdom), but this kind of knowledge always remains insufficient for historical understanding. Le Roux emphasises that something more is needed, namely the 'inside story'. He puts it as follows:

Knowledge of an event's 'inside' is also required: that which can only be determined in terms of thought. An Old Testament scholar's main task is to think himself [sic] into actions of Israel's past and 'to discern the thought of the agent' (with reference to Collingwood, again). (Le Roux 1998:484)

How does this happen? How do we enter the 'inside' of an event? Le Roux's answer to this is (with reference to Gunkel) very simple, but also very complex: 'By means of spiritual empathy' (1998:484). Le Roux (1998) explains:

[Spiritual empathy] enables the researcher to enter into the past, to give it life and blood, and to make the past present ... Knowledge of the past can be gained when the past is re-enacted in the mind of the historian .... (p. 484)

Interest in the past is therefore not an attempt to grasp the events of the past, but rather an attempt to relive the past, to creep into the mind of those who articulated their 
understandings in the past. However, one should realise that this can only be done analogically. There is no way of providing an ontic description of past thoughts and motivations. But, on account of a common humanity, past readers and present readers of ancient texts can connect through historical understanding. This common humanity can assist us in interpreting the traces of the past that we see in the Old Testament.

Le Roux (2010:512) explains this very practically when he discusses the role of recent Pentateuch scholarship ${ }^{14}$ in the South African context:

The Pentateuch's meaning is ... linked to [the] dialogical process of asking (historical) questions: What was the original question? What were the circumstances? To what is this or that section of the Pentateuch an answer? To whom was it directed? How did the editors interpret and formulate the answer? Et cetera. The Pentateuch is an answer to the questions that lived in the hearts of people. At specific junctures in Israel's history certain questions were posed and the various redactions of the Pentateuch are attempts to provide answers to these questions. Traces of the original questions and answers can still be detected and the scholar must endeavour to determine the original questions with which the authors grappled. (p. 512)

At this point I would like to move on to my own attempt at describing what historical consciousness means particularly when articulated within a multidimensional frame of understanding. However, one important point which emerged in the discussion of Le Roux's explanation of historical understanding is worth emphasising: Le Roux endeavours to study the texts in order to re-enact the past. This re-enactment is, however, no attempt to resurrect the past events, but rather to feel with (see again his use of the word 'empathy') those people who articulated in the Old Testament texts their grappling with socio-political, socioreligious and socio-economic issues in their own context. One should therefore notice that Le Roux's historical understanding is contextual - both in terms of his own context and the context of those who produced the texts. ${ }^{15}$ Historical understanding takes place where a fusion of these contexts, or horizons (à la Gadamer), takes place.

\section{Historical consciousness and contextuality}

The history of Old Testament scholarship in South Africa has been characterised - at least until the beginning of the 1990s - by 'a story of two ways' (See Le Roux 1993a) These two ways were the historical-critical approaches followed by some and the text-immanent approaches followed by

14.Pentateuch scholarship is, according to Le Roux, an attempt to find the questions to which the Pentateuch (in all its layers of growth) provides the answers.

15.See his formulations in Le Roux (1993b:45-46): 'As far as the historical document is concerned two settings can be discerned: the one in which it originated and the one in which it lived and was interpreted, that is, origin and existence. It originated in a specific context and was produced by people who were shaped by their context. In other words: they were conditioned by their times. More
is, however, involved than the origin: the historical writings have existed over is, however, involved than the origin: the historical writings have existed over
several centuries and have been interpreted. And these later interpretations were also determined by the philosophy and theology during this period of the text's existence. The historian is also influenced by the context in which he lives ... It is existence. The historian is also influenced by the context in which he lives ... It is
extremely difficult to transcend this context and therefore its interpretative force must be acknowledged.' others (particularly since the 1970s). The main dichotomy in this phase of local scholarship until the 1990s was between the extremes of those who insisted on the inclusion of the historical in their exegesis, and those who opted for an a-historical (or even antihistorical) focus on the structures and signs in texts. ${ }^{16}$ As we have seen above, this dichotomy developed under the influence of global trends, not only in biblical scholarship, but also in literary science in general.

However, since the 1990s another dichotomy developed in South African biblical scholarship, namely the dichotomy between so-called contextual and non-contextual approaches. Under the influence of the hermeneutical shift to the role of the reader and the advent of postcolonial modes of thinking, many approaches started developing, as I have indicated above, which emphasised that biblical interpretation always takes place from specific social locations which should be taken seriously. Often the accusation was, and still is, voiced that detached biblical scholarship (both of historical-critical and text-immanent flavour) is irrelevant to flesh-and-blood reading communities who live by these texts.

This second 'story of two ways' which developed since the 1990s is in my estimation very important to analyse. It is interesting that there is a move away from the binary opposition of historical versus a-(anti-)historical readings, to another supposed opposition between contextual versus non-contextual (which is normally associated with traditional, western, historical scholarship) readings. What should not go unnoticed in the development of this new dichotomy, however, is the return of the historical. Many contextual approaches to biblical interpretation thrive on historical approaches: from the use of traditional historicalcritical scholarship in liberation and feminist hermeneutics, to cultural-historical and sociological approaches in postcolonial and comparative approaches.

The present dichotomy (which I will, again, deconstruct below) is therefore no longer a quarrel about the role of the historical in biblical interpretation, like in the former 'story of two ways'. Both sides of the present dichotomy would be willing to agree on the importance of including a historical dimension in biblical interpretation.

I am not convinced, however, that the present dichotomy is really a binary opposition between sensitivity to context versus insensitivity to contextual understanding. The majority of historical-critical approaches (if not all) take the different contexts of textual origin seriously, whilst the socalled contextual approaches take their point of departure in the different contexts of textual reception. The issue at stake is therefore not contextual awareness or sensitivity. It is rather a debate about whether contexts of textual production should dominate our interpretations of the Bible, or rather contexts of textual reception.

If this analysis is accepted, I would like to proceed with a further deconstruction of the present dichotomy between

16.Le Roux (2010:508) describes the a-(anti-)historical approaches in the South African context as 'Pentateuch anger'. 
contexts of textual production versus contexts of textual reception. In previous publications I have indicated that at least in the case of the Old Testament, which originated over many centuries - this is an unwarranted distinction. At least, one should realise the close analogy between textual production and textual reception. Whether one would view this from a postmodern perspective of intertextuality where later texts are seen as carrying the traces of earlier texts (not only literary texts, but texts understood in the broadest sense) (See Jonker [1999]), or whether one would take the perspective of inner-biblical exegesis where later texts are seen as appropriations of earlier texts in changed contexts (See Jonker [2011]), it becomes clear that textual production leads to textual reception leads to renewed textual production. The development of the Old Testament over centuries is therefore a product of continual contextual reception. Contextual reception is therefore not something which only becomes relevant in our present contemporary contexts. Contextual reception - from ancient biblical times through to our modern (or even, postmodern) times - is all we have.

I therefore find it no surprise that within the present 'story of two ways' in South African Old Testament scholarship contextual approaches are increasingly building upon historical perspectives in their analyses, whilst historical approaches show greater awareness of the contextuality of their interpretations (such as in Le Roux's views discussed above). Historical and contextual understanding therefore cuts both ways, and perhaps even shapes the 'story of two ways' into a story of one way with various, complementary, lanes.

\section{Conclusion}

\section{Why history matters}

This discussion brings me back to the original question which I set out to answer in this contribution: Why does history matter in our (South African but also global) interpretation of the Old Testament? I conclude that history matters in our interpretations because contextual reception is all that we have available! Interpretation without a historical dimension cannot be contextual; and interpretation without a sensitivity to context cannot be historical. Contexts of reception of biblical literature span over many centuries. Some may prefer to explore the traces of the past in the biblical texts in order to relive and re-enact the past, and to figure out which questions stood behind the answers provided in the texts, knowing that they are doing these investigations from their own (post)modern contexts which influence their interpretations thoroughly. This mode of biblical interpretation will be highly beneficial to articulate the continuities and discontinuities with the biblical past in order to determine how they impact on their present and future. Others may prefer to explore the contextual contours of contemporary society and contemporary reading communities in order to help articulate with those communities their deepest needs and convictions. That mode of biblical interpretation will also be highly beneficial to articulating their continuities and discontinuities with the biblical past in order to determine how they impact on their present and future. History (whether ancient or contemporary) matters in order to grasp the full implications of context in biblical interpretation.

The 'historical consciousness' that is implied here should therefore not be confused with a longing for a past which is forever lost, or with an optimism that the intentions of the original authors can be reconstructed. Historical consciousness is rather the reader- or context-oriented appreciation of the contexts of textual production and of textual reception (from ancient times, throughout the ages, up to modern-day receptions in various and differing circumstances).

\section{Acknowledgement Competing interests}

The author declares that he has no financial or personal relationship(s) which may have inappropriately influenced him in writing this article.

\section{References}

Albertz, R., 1992, Religionsgeschichte Israels in alttestamentlicher Zeit, Part 1 and 2 Vandenhoeck \& Ruprecht, Göttingen. PMid:20733643

Albertz, R. \& Schmitt, R., 2012, Family and household religion in Ancient Israel and the Levant, Eisenbrauns, Winona Lake, IN.

Bosman, H.L., 1992, 'Fallacy or fountainhead? Authorial intention and historicalcritical interpretation', in W. Wessels \& E. Scheffler (eds.), Old Testament Science and Reality, pp. 20-32, Verba Vitae, Pretoria.

Collins, J.J., 2005, The Bible after Babel. Historical criticism in a postmodern age, Eerdmans, Grand Rapids, MI.

Combrink, H.J.C., 1979, Structural analysis of Acts 6:8-8:3, NG Kerkboekhandel, Cape Town. PMid:16660903, PMCid:543041

Davies, P.R., n.d., Minimalism, 'Ancient Israel', and Anti-Semitism, viewed 01 June 2012, from http://www.bibleinterp.com/ articles/Minimalism.shtml

Davies, P.R. (ed.), 2010, The historian and the Bible. Essays in honour of Lester L. Grabbe, T\&T Clark, London.

Farisani, E., 2002, 'The use of Ezra-Nehemiah in a quest for theology of renewal, transformation and reconstruction in the (South) African context', DTh dissertation, University of KwaZulu-Natal.

Grabbe, L.L., 2004, A history of the Jews and Judaism in the Second Temple Period. Volume 1. Yehud: A history of the Persian Province of Judah, T\&T Clark, London.

Hardmeier, C., 2001, Steine - Bilder - Texte. Historische Evidenz ausserbiblischer und biblischer Quellen, Evangelischer Verlagsanstalt, Leipzig.

Jonker, L.C., 1999, 'Communities of faith as texts in the process of biblical interpretation', Skrif en Kerk 20(1), 79-92.

Jonker, L.C., 2011, “'Lewend en kragtig”? Die hermeneutiese dinamika en implikasies van (her)interpretasie in die Ou Testament', Nederduits Gereformeerde Teologiese Tydskrif 52(1\&2), 128-147.

Jonker, L.C. \& Lawrie, D., 2005, Fishing for Jonah (anew). Various approaches to biblical interpretation, Sun Press, Stellenbosch.

Le Roux, J.H., 1993a, A story of two ways. Thirty years of Old Testament scholarship in South Africa, Old Testament Essays Supplement 2, Verba Vitae, Pretoria.

Le Roux, J.H., 1993b, 'The nature of historical understanding (or: Hermeneutics and history)', Studia Historiae Ecclesiasticae 19(1), 35-63.

Le Roux, J.H., 1997, “Our historical heritage', Old Testament Essays 10(3), 401-423.

Le Roux, J.H., 1998, 'Israel's past and the feeling of loss (or: Deconstructing the 'minimum' of the 'Minimalists' even further', Old Testament Essays 11(3), 477-486.

Le Roux, J.H., 2007a, 'Historical understanding and rethinking the foundations', HTS Teologiese Studies/Theological Studies 63(3), 983-998. http://dx.doi. org/10.4102/hts.v63i3.241

Le Roux, J.H., 2007b, 'Setting the scene: The battle of the signs', in J.H. le Roux \& E. Otto (eds.), South African Perspectives on the Pentateuch between synchrony and diachrony, pp. 1-18, T\&T Clark, New York.

Le Roux, J.H., 2010, 'Searching for a question and an answer', in R. Achenbach (ed.) 'Gerechtigkeit und Recht zu üben' (Gen 18, 19): Studien zur altorientalischen und biblischen Rechtsgeschichte, zur Religionsgeschichte Israels und zur Religionssoziologie. Festschrift für Eckart Otto zum 65. Geburtstag, pp. 508-517, Harrassowitz, Wiesbaden. 
Masenya, M., 1996, 'Proverbs 31:10-31 in a South African context. A Bosad (Womanhood) perspective', DLitt et Phil dissertation, University of South Africa.

McKenzie, S.L., 2005, How to read the Bible. History, prophecy, literature - Why modern readers need to know the difference, and what it means for faith today, Oxford University Press, Oxford.

Nzimande, M., 2005, 'Postcolonial biblical interpretation in post-apartheid South Africa: The Gebirah in the Hebrew Bible in the light of Queen Jezebel and th Queen Mother of Lemuel', PhD dissertation, Brite Divinity School, Fort Worth.

Prinsloo, W.S., 1988, Van kateder tot kansel: 'n Eksegetiese verkenning van enkele Psalms, NG Kerkboekhandel, Pretoria.

Schmid, K., 2008, Literaturgeschichte des Alten Testaments. Eine Einführung. Wissenschaftliche Buchgesellschaft, Darmstadt.

Schmid, K., 2011, Schriftgelehrte Traditionsliteratur: Fallstudien zur innerbiblischen Schriftauslegung im Alten Testament, Mohr-Siebeck, Tübingen.
Smend, R., 2007, From Astruc to Zimmerli. Old Testament scholarship in three centuries, transl. M. Kohl, Mohr-Siebeck, Tübingen.

Thompson, T.L., 1999, The Bible in history: How writers create a past, Jonathan Cape, London.

Ukpong, J. et al. (eds.), 2002, Reading the Bible in the global village: Cape Town, SBL Press, Atlanta.

West, G.O., 1995, Biblical hermeneutics of liberation: Modes of reading the Bible in the South African context, 2 nd rev. edn., Cluster, Pietermaritzburg.

West, G.O., 2005, 'Shifting perspectives in the comparative paradigm in (South) African biblical scholarship', Religion and Theology 12(1), 48-72. http://dx.doi. org/10.1163/157430105X00121

West, G.O., 2008, 'Doing postcolonial biblical interpretation @ home: Ten years of (South) African ambivalence', Neotestamentica 42(1), 147-164.

Wimsatt, W.K. \& Beardsley, M.C., 1954, 'The intentional fallacy', in W.K. Wimsatt (ed.), The verbal icon, pp. 3-18, University of Kentucky Press, Lexington. 